\title{
AUSTRALIA PLANNING REPORT CARD - TELLING IT LIKE IT IS!
}

\author{
Liz de Chasterl ${ }^{1}$ \\ National Policy Manager. \\ PLANNING INSTITUTE OF AUSTRALIA
}

\section{OVERVIEW}

Are we doing what is needed in the critical areas for creating effective, functional and sustainable cities, towns, neighbourhoods and regions? Every year Australian planning professionals are asked by the Planning Institute of Australia (PIA) for their expert opinions on how we are performing in key areas critical to the health and wellbeing of our cities.

The first poll was conducted in 2006. The results, released on World Town Planning Day, 8 November, attracted considerable media, political and community interest. In 2007 over 740 planners responded to the survey 'telling it like it is' and more respondents are expected in 2008.

This article provides an overview of the Planning Report Card and more detailed information can be found at the PIA web site at http://www.planning.org.au/index.php?option $=$ com content\&task=view\&id $=54$ $\underline{78 \text { Itemid }=485}$.

\section{WHY IS THE PLANNING INSTITUTE OF AUSTRALIA DOING THIS REPORT CARD?}

Planners and PIA want to work with planning decision makers and industry to support best practice, highlight what is important, congratulate those responsible for a job well done, and ensure everyone knows where more work is needed.

PIA is concerned about planning in Australia and about the health and wellbeing of our cities, towns and neighbourhoods. It wants to raise the profile of planning and the importance of sound planning to our lives. PIA also wants

' policy@planning.org.au. 
to be part of identifying solutions and doing things better in partnership with all the other players that help create great communities and places.

Planners cannot achieve improvements alone. We work in a collaborative system with government decision makers, local councilors, developers and the community all have a role to play. How well the planning system operates relies on all those players pulling together to produce $\mathrm{A}+$ performances.

There are some big issues facing Australian cities and towns. Australia is one of the most urbanized countries in the world. Over $85 \%$ of the people live within 50 kilometres of the coastline and most of these in the 7 major cities. These cities, towns and regions are where most Australians live, do business, get educated and participate in community life. They generate $85 \%$ of our nation's GDP.

Australia has some great challenges to face in the next $20-50$ years. We need to tackle them effectively to ensure that future generations are able to enjoy the same levels of prosperity as we do.

We all know that climate change is expected to impact on our cities and towns in a variety of ways - such as an increase in severe weather events, rising sea levels, inundation and drought conditions. Many regions of Australia are already feeling the effect of these impacis, through tough water restrictions or property damage from severe storms.

Our ageing population is also placing pressure on our health and transport systems and demands are increasing for alternative forms of housing to meet the need of our elderly population.

Public transport will become increasingly important if the likely trend for increased fuel prices continues. The affordable housing crisis is now causing social and economic stress on a large part of the community.

To ensure we are ready to meet the challenges facing our cities and towns we need to have effective planning and investment in infrastructure and a commitment to sustainable, liveable cities, regions and neighbourhoods.

We must have effective planning to integrate land use, transport, water, growth pressures and housing. Without effective planning systems we are losing opportunities to keep our cities competitive and vibrant. 


\section{GOVERNMENT INPUT}

In 2007 following feedback from the 2006 survey we approached all State and Territory Planning Ministers and, given the Federal Election that was held in November 2007 all the political parties at the federal level, to detail policy plans and initiatives underway against the 12 Report Card criteria.

Responses received from Governments and political parties before the survey was released, were made available to planners to ensure they knew the strategies underway when rating performance. These responses, and those received after the survey, were made available on the PIA website.

Most Governments and political parties took the opportunity to respond and it is uplifting to see the positive initiatives being taken in so many states against the Report Card criteria

\section{TWELVE CRITERIA}

This year we added climate change and urban design to last year's $10 \mathrm{critical}$ planning criteria that we believe should be in place for effective planning. We derived these criteria from PIA's Sustainable Communities policy platform and the priorities identified by PIA's members -4500 professionals from around Australia.

The survey asked planners to rate performance against these 12 criteria

\section{Growth Management}

How is your state/territory performing in developing and approving growth management plans for regions that integrate social, economic, environmental and transport issues?

\section{Sustainability Indicators}

How is your state/territory performing in developing sustainability indicators that can be used to measure the performance of plans?

\section{Governance}

How is your state/territory performing in having governance structures that support the development and implementation of effective growth management plans? 


\section{Infrastructure}

How is your state/territory performing in having a timetable and funding commitment for major social and physical infrastructure in accordance with a growth management plan?

\section{Transport}

How is your state/territory performing in having a commitment to fund improvement and expansion of public transport integrated with a growth management plan?

\section{Demographic Change}

How is your state/territory performing in developing a sea change/tree change strategy to address the impacts of population shifts?

\section{Housing}

How is your state/territory performing in developing a housing strategy that addresses affordability, housing choice and sustainable design?

\section{Public Participation}

How is your state/territory performing in having effective mechanisms for public participation in developing planning strategies?

\section{Planning Workforce}

How is your state/territory performing in having a well resourced and skilled professional workforce to provide expertise to the planning process?

\section{Streamlined Assessment}

How is your state/territory performing in having a streamlined planning assessment in place?

\section{Urban Design}

How is your state/territory performing in having clear policies that promote quality buildings and urban spaces?

\section{Climate Change}

How is your state/territory performing in having a strategy to mitigate and adapt to climate change? 
Respondents were asked to rate the above criteria using the following scores:
A Performing well against this criterion (80-100\%)
B Doing well against this criterion with some initiatives underway $(70-79 \%)$
C Evidence of some initiatives with improvement required to reach this criterion (60-69\%)
D Inadequate progress in this criterion (50-59\%)
E No progress $(<49 \%)$

PIA is also developing national position statements on all of the above 12 criteria, outlining what it believes are essential elements and action for effective performance of each criteria.

\section{THE 2007 RESULTS}

This survey tool is intended to illustrate how Australia, state by state, is performing in planning terms. This assessment is intended to be constructive, highlighting our successes as well as identifying where we can do better.

The frustrations of the planning community with the speed of progress, the impediments to change and the lack of investment in planning, shows through again this year in the comments provided by respondents.

The survey results are summarised in the table below (Table 1). The results indicate that overall Australia has scored a $\mathrm{C}$. This means there is evidence of some initiatives being taken in the 12 key areas nationally, but that improvement is needed to meet the levels of commitment, activity and funding needed to produce effective outcomes. Australia-wide we are performing reasonably well (with some caveats) in three of the twelve criteria:

- Growth Management

- Public Participation

- Streamlined Assessment

Australia is also doing moderately well in terms of Urban Design and Governance. We are doing less well, however, against the remaining seven criteria. Some states and territories are continuing to take positive steps to get it right. The strong performances which rated $\mathrm{C}+$ on the national table include: 
- Western Australia - Transport Planning and Public Participation

- South Australia-Streamlined Development Assessment

- Victoria-Public Participation

- Queensland and Australian Capital Territory - Growth Management

- Australian Capital Territory-Public Participation

In terms of the positives, no more than $60 \%$ of respondents rated their state $\mathrm{A}$ or $\mathrm{B}$ against any criterion and some states/ territories received no $\mathrm{A}$ scores at all against any criteria. So, there is still a lot more to be done. (The Northern Territory had a low respondent rate and its results have therefore not been included.)

\section{CONCLUSION}

Many people influence the built environment - state and federal politicians, local government councilors, professionals, community, public servants, developers and many others. They impact on our cities, towns and regions through their decisions in terms of funding, regulation, development proposals and design.

This opinion poll gives the profession an opportunity to reflect on the current state of our planning systems and outcomes. Planners are qualified and well placed to tell us how well we are doing.

The Planning Institute of Australia believes that an annual, honest look at the way our planning systems are operating is an important way to remind us all of the importance of these issues. 
Table 1: Planning Report Card - National results

\begin{tabular}{|c|c|c|c|c|c|c|c|c|}
\hline STATE & NSW & ACT & QLD & VIC & SA & TAS & WA & NATIONAL \\
\hline $\begin{array}{r}\text { Growth } \\
\text { management }\end{array}$ & C & $C+$ & $\mathrm{C}+$ & C & C & D & C & C \\
\hline $\begin{array}{l}\text { Sustainable } \\
\text { Indicators }\end{array}$ & C- & C & C- & C & C & $D+$ & C & C.- \\
\hline Governance & C- & C & C & C & C & D & C & C \\
\hline Infrastructure & D & C & C & C- & $\mathrm{D}+$ & D & C & C- \\
\hline Transport & D & $D+$ & C & D & $D+$ & D- & B- & C- \\
\hline $\begin{array}{r}\text { Demographic } \\
\text { Change }\end{array}$ & $\mathrm{D}+$ & C- & C & C & C- & $D$ & C- & C- \\
\hline Housing & $\mathrm{D}+$ & C & C- & C- & C & $D+$ & $D+$ & C- \\
\hline $\begin{array}{r}\text { Public } \\
\text { Participation }\end{array}$ & C- & $\mathrm{C}+$ & C & $\mathrm{C}^{+}$ & C & C & B- & C \\
\hline $\begin{array}{r}\text { Planning } \\
\text { Workforce }\end{array}$ & D- & C- & $D+$ & C- & C- & C- & $D+$ & C- \\
\hline $\begin{array}{l}\text { Streamlined } \\
\text { Assessment }\end{array}$ & $D+$ & C & C. & C & $\mathrm{C}+$ & C & C. & C \\
\hline Urban Design & C & C & C- & c & C- & D & C & C \\
\hline $\begin{array}{l}\text { Climate } \\
\text { Change }\end{array}$ & $\mathrm{D}+$ & C & $\mathrm{D}+$ & C- & $C$ & C- & D+ & C- \\
\hline $\begin{array}{l}\text { AVERAGE } \\
\text { GRADE }\end{array}$ & $D+$ & C & C & C & c & $D \div$ & C & C \\
\hline
\end{tabular}




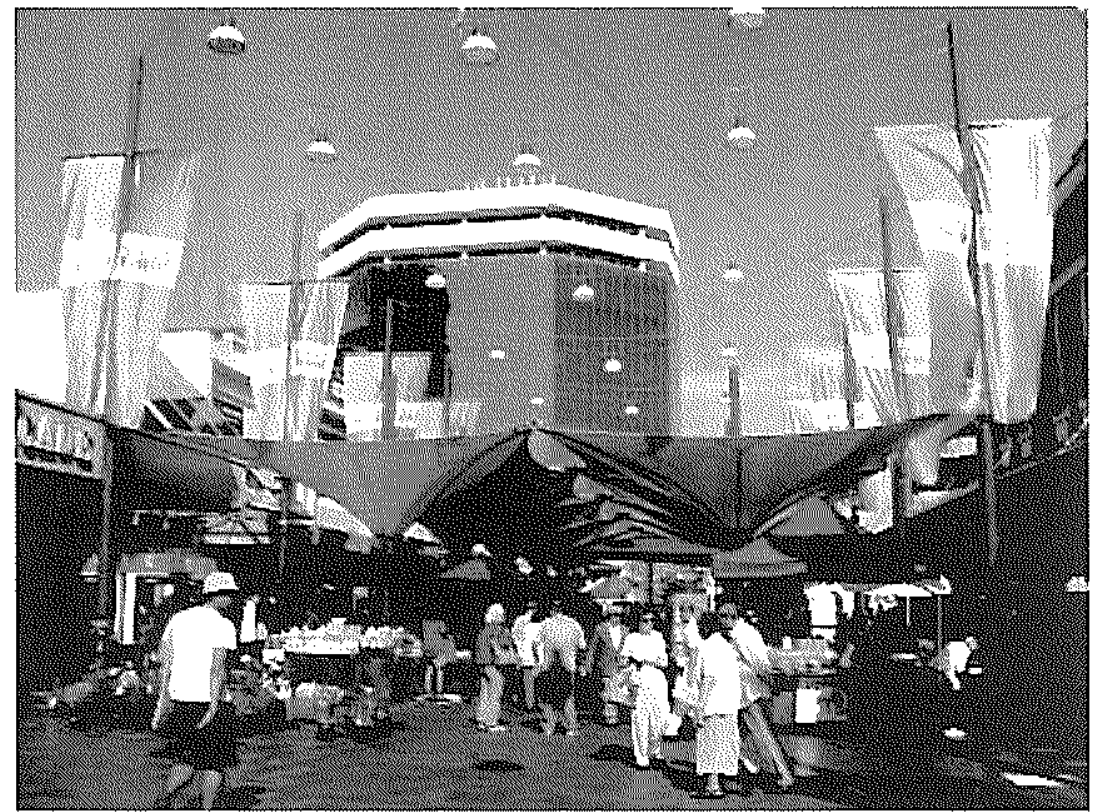

Picture 1: Bondi Junction Mall2, February 2008

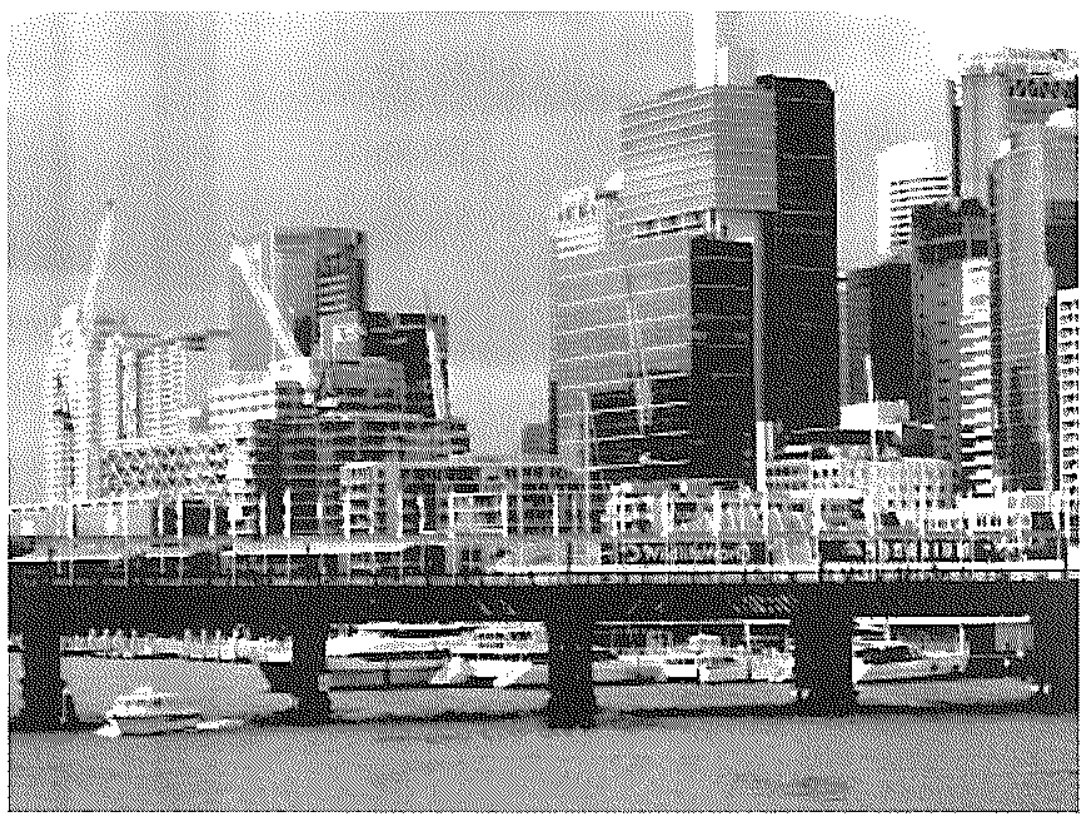

Picture 1: Darling Harbour Bridge Sydney, April 2008 




Picture 3: Express Freeway1 Brisbane, October 2007

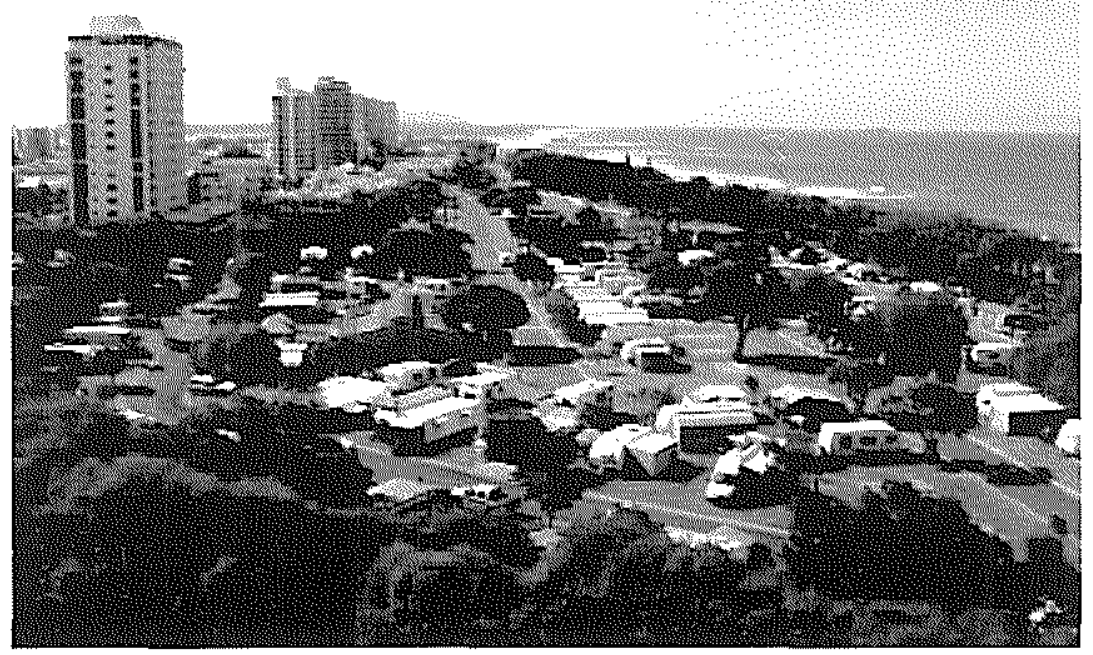

Picture 4: Maroochydore foreshore, 2006 
